\title{
Variability in the distribution and dissipation of the herbicide thifensulfuron- methyl in a prairie wetland
}

\author{
J.A. Elliott and A.J. Cessna
}

\begin{abstract}
Surface runoff, atmospheric transport, spray drift, and other transport processes result in frequent herbicide detections in prairie dugouts and wetlands. Thifensulfuronmethyl is a commonly used sulfonylurea herbicide with high phytotoxicity that could pose a potential threat to wetland ecosystems. The dissipation of thifensulfuron-methyl in a prairie wetland was monitored in the water column and wetland sediments during four months following herbicide addition.Variability in herbicide concentrations relative to physico-chemical characteristics of the wetland was evaluated by collecting water samples for herbicide analysis from two locations near the middle of the wetland and at two depths $(0.5 \mathrm{~m}$ [1.6 ft] below the surface and $0.1 \mathrm{~m}[0.3 \mathrm{ft}]$ above the wetland floor) at each location. Sediment samples were collected beneath the water sampling locations and at two sites near the wetland margin. Water temperature was constantly monitored throughout the study period, and a range of wetland properties was measured at each sampling. Higher temperatures and greater diurnal fluctuations were measured at $0.5 \mathrm{~m}$ depth than at $0.1 \mathrm{~m}$ from the bottom. Conversely, electrical conductivity of the wetland water was consistently greater at depth than near the surface of the wetland. Concentrations of thifensulfuron-methyl were consistently higher at $0.5 \mathrm{~m}$ depth than at $0.1 \mathrm{~m}$ from the bottom. Dissipation of thifensulfuron-methyl was biphasic at both depths, dissipating more rapidly initially (most of the herbicide was lost from the water column after 7 days) such that initial time for $50 \%$ dissipation values were around 2 days. Dissipation in the second phase proceeded at a much slower rate, taking three to five weeks for $50 \%$ of the residual herbicide to dissipate (quantifiable concentrations were still measured after 128 days). Thifensulfuron-methyl was detected in sediments collected near the wetland edge but not in samples taken from the deeper parts of the wetland. The physico-chemical environment of the wetland (temperature, $\mathrm{pH}$, and dissolved oxygen [DO]) affected the distribution of thifensulfuron-methyl and should be considered in the development of sampling regimes and pesticide fate models.
\end{abstract}

Key words: environmental fate- pesticide — sediment — temperature — water chemistry

\begin{abstract}
Pesticides are frequently detected in North American wetlands. Wetland ecosystems in the prairie pothole region provide water and cover for wildlife and waterfowl and are critical breeding habitat for a large proportion of the continental duck population (Batt et al. 1989). They also support rich and diverse communities of aquatic plants, animals, and microorganisms (Millar 1976; Hartland-Rowe 1966). Hydrologically, the wetlands act as collection basins for groundwater recharge providing a link between surface and groundwater (Meyboom 1966; van der Kamp and Hayashi 1998).
\end{abstract}

Agriculture is the predominant land use in the prairie pothole region, and many prairie wetlands are located within cropland. Management of the land-water interface varies between wetlands and ranges from well-developed buffer zones to cultivated wetland margins (Xu et al 2009). Agricultural pesticides can enter the wetlands through a variety of pathways including application drift (Wolf et al. 2003), wet and dry deposition (Yao et al. 2006), surface runoff, and shallow subsurface flow (Grover 1988). In a survey of 51 prairie wetlands in Saskatchewan, Canada, Donald et al. (1999) found three herbicides (MCPA; 2,4-D; and triallate) in excess of Canadian Water Quality Guidelines for the protection of aquatic life $\left(2.6,4\right.$, and $0.24 \mu \mathrm{g} \mathrm{L}^{-1}$ [2.6, 4 , and $0.24 \mathrm{ppb}$, respectively; CCME 2013). Although detected in the largest proportion of wetlands, 2,4-D and MCPA exceeded the guideline in only 1 and 2 wetlands, respectively, while triallate was less frequently detected but exceeded the guideline in $25 \%$ of the surveyed wetlands. The authors concluded that agricultural pesticides were present in prairie wetlands at levels that threatened their ecological integrity.

Numerous other studies have monitored pesticide concentrations in prairie wetlands or dugouts in relation to pesticide application on adjacent fields (Cessna and Elliott 2004) or land use or management practices (Donald et al. 2001; Elliott et al. 2001). In these studies, pesticide detections were not clearly related to recent applications in the watershed of the wetland. The presence of pesticides was attributed to atmospheric deposition (Donald et al.2000) and release of previously applied pesticides from storage in the wetland bottom sediments (Cessna and Elliott 2004; Elliott et al. 2001). Despite speculation that bottom sediments are a source of pesticides found intermittently in the water columns of prairie wetlands, few studies have measured pesticide concentrations in wetland sediments. In a survey of 19 lakes in Saskatchewan, Donald and Syrgiannis (1995) detected 5 of a suite of 11 commonly used herbicides in up to $39 \%$ of bottom sediment samples. More recently, Degenhardt et al. (2010) surveyed sediments in 17 wetlands in Manitoba and Saskatchewan, Canada, for a suite of 7 sulfonylurea herbicides. Sulfonylureas are a relatively new class of herbicides that are not yet covered by Canadian Water Quality Guidelines despite being highly phytotoxic at low concentrations, which suggests a potential to impact aquatic life. Ethametsulfuron-methyl was detected in $100 \%$ of samples and at concentrations greater than the limit of quantification $\left(1 \mu \mathrm{g} \mathrm{kg}^{-1}\right)$ in $39 \%$ of samples. The least commonly detected sulfonylurea

Jane Eltiott is a research scientist with Environment Canada and Allan Cessna is a research scientist with Agriculture and AgriFood Canada. Both authors work at the National Hydrology Research Centre in Saskatoon, Saskatchewan, Canada. 
herbicides were thifensulfuron-methyl (methyl 3-[[[[\{4-methoxy-6-methyl-1,3,5,triazin-2-yl\} amino]carbonyl]amino] sulfonyl]-2thiophenecarboxylate) and tribenuron-methyl, which could not be quantified in any of the samples but which were present in trace amounts in 39\% and $23 \%$ of samples, respectively.

Herbicide dissipation rates in wetland waters and sediments are most commonly measured in laboratory microcosms or in wetland mesocosms (Goldsborough and Crumpton 1998; Katagi 2006) where there is some control on environmental conditions, but dissipation has also been monitored in farm dugouts (artificial ponds dug to store runoff water for farm use) and prairie wetlands (Cessna et al. 2006; Degenhardt 2010; Degenhardt et al. 2011). Cessna et al. (2006) calculated time for 50\% dissipation (DT50) values (time for 50\% dissipation) ranging from 16 to 84 days for three sulfonylurea herbicides in the water column of farm dugouts while Degenhardt and coworkers studied dissipation of glyphosate (Degenhardt 2010) and a suite of six acid herbicides (Degenhardt et al. 2011) in wetland water and their partitioning into sediments. In general, $\mathrm{DT}_{50}$ values for these seven herbicides in the water column of the wetlands ranged from 2 to 26 days. The proportion of the amount of each herbicide added to the wetlands that partitioned into sediment varied from $1 \%$ and $67 \%$ and depended, in part, on the measured sorption coefficients of the wetland sediments (Xu et al. 2009).

Usually, studies to monitor herbicides in the water columns of prairie wetlands and dugouts rely on samples taken near the center of the water body at a standard sampling depth, which could be the midpoint of water column or at a fixed depth below the water surface near the center of the water body (Degenhardt et al. 2010; Detenbeck et al. 2002). However, Cessna and Elliott (2004) found some evidence of stratification reflected in the herbicide concentrations measured at two depths in the farm dugouts they were monitoring. The use of mesocosms precludes the influence of the temporal and spatial range of conditions that occur in natural wetlands (Goldsborough and Crumpton 1998). Katagi (2006) reported that stratification rarely persisted more than one or two days in the water columns of microcosms and mesocosms, but Day et al. (1987) found that concentration gradients disappeared more slowly in deeper water columns. The variability of physico-chemical conditions in a natural wetland will affect both the distribution and dissipation of a pesticide within the wetland. Our objective was to study the spatial variability in concentrations and dissipation of the most commonly applied sulfonylurea herbicide (thifensulfuron-methyl) in a prairie wetland relative to the variation in physical (temperature) and chemical $(\mathrm{pH}$, electrical conductivity [EC], dissolved organic carbon [DOC], and dissolved oxygen [DO]) characteristics of the water.

\section{Materials and Methods}

Site and Herbicide Treatment. The study was conducted in a wetland situated in the St. Denis National Wildlife Area near Saskatoon, Saskatchewan, Canada. The wetland was located in a 5 ha $(12 \mathrm{ac})$ catchment in a gently undulating to hummocky glacial till landscape overlain by loam-textured soils classified as Typic Borolls of the Weyburn Association by Acton and Ellis (1978). Wheat (Triticum aestivum) and flax (Linum usitatissimum) were grown in the catchment in the study year. The wetland measured approximately $30 \mathrm{~m}$ (98 ft; north to south) by $20 \mathrm{~m}$ (66 ft; east to west) and was approximately $1.4 \mathrm{~m}(4.6 \mathrm{ft})$ deep at its deepest point. Most of its catchment was to the north where a well-defined channel entered at the end of the wetland. A grassed buffer about $10 \mathrm{~m}$ (33 $\mathrm{ft}$ ) wide transitioned into cattails (Typha latifolia) at the wetland margin that extended several meters into the wetland where they were replaced by duckweed (Lemna minor), a floating vascular plant. As part of an ecological effects study, the wetland was divided into two independent sections using a geosynthetic polyvinyl curtain that was fitted to the cross-sectional contour of the wetland bottom. Placement of the bottom of the curtain into the bottom sediments to seal the partition was ensured by fixing logging chain to the bottom of the curtain. A cable inserted through a pocket sewn across the width of the curtain maintained the top of the curtain approximately $16 \mathrm{~cm}$ (6 in) above the surface of the wetland. At time of installation (June $7,2005)$, the volume of water in the north section was calculated to be approximately $150 \mathrm{~m}^{3}\left(5,297 \mathrm{ft}^{3}\right)$ while that in the south section was approximately $200 \mathrm{~m}^{3}\left(7,063 \mathrm{ft}^{3}\right)$.

Because the majority of the catchment drained into the north section of the wetland, the south section was selected for addition of thifensulfuron-methyl. This ensured that if rainfall runoff occurred during the study, the majority of the runoff would enter the north (untreated control) section of the wetland and herbicide concentrations in the south section would be minimally compromised by dilution. The south section of the wetland was treated with thifensulfuron-methyl on June 14,2005 , with the intent to reach an environmentally relevant target concentration of 12 $\mu \mathrm{g} \mathrm{L}^{-1}$ (12 ppb). It should be noted that the chosen target concentration was somewhat higher than that calculated by Cessna et al. (2006) to represent a worst case scenario of an accidental overspray of a pond $0.5 \mathrm{~m}(1.6 \mathrm{ft})$ deep $\left(3 \mu \mathrm{g} \mathrm{L}^{-1}[3 \mathrm{ppb}]\right)$. We chose to increase the concentration four-fold to increase the likelihood of quantifying herbicide concentrations in the wetland sediments.

To add the herbicide to the wetland, $2.4 \mathrm{~g}$ $(0.08 \mathrm{oz})$ of thifensulfuron-methyl in a stock solution was split into two equal portions, each of which was diluted in approximately $10 \mathrm{~L}$ (2.6 gal) of water in a hand-held sprayer. The herbicide was applied from a boat that was guided back and forth across and along the wetland using ropes on either side. The nozzle of the sprayer was held just below the water surface to ensure that all of the application entered the wetland.

Two water and sediment sampling locations ( $\mathrm{T} 1$ and $\mathrm{T} 2$ ) were established in the treated portion of the wetland, and a third control location (C) was located in the untreated portion. All of the sampling locations were on the centerline of the wetland. The control location was $4 \mathrm{~m}(13 \mathrm{ft})$ north of the curtain, T1 was $4 \mathrm{~m}$ south of the curtain, and T2 was midway between T1 and the south edge of the wetland. When the herbicide was applied, the water depths at the sampling points were $1.19,1.37$, and 1.18 $\mathrm{m}(3.90,4.49,3.87 \mathrm{ft})$ for $\mathrm{C}, \mathrm{T} 1$, and T2, respectively. Additional sediment sampling locations were established at the edge of the vegetation on the west side of the wetland and in line with the T1, T2, and C sampling locations (T3, T4, and $\mathrm{C} 2$, respectively).

Sampling. Baseline samples from the wetland were collected on June 9, 2005. However on June 10, 2005, the producer sprayed 3 ha $(7 \mathrm{ac})$ of spring wheat in the catchment to the east of the wetland with Refine Extra, which contains $50 \%$ thifensulfuron-methyl as a dry flowable (Dupont Canada Inc.). Since this application contained approxi- 
mately $30 \mathrm{~g}(1 \mathrm{oz})$ of our target herbicide, a second subset of baseline samples were collected on June 13, 2005, to ensure that the application had not drifted into the wetland. Subsequent sampling days were 1 (June 15), $2,3,7,14,21,28,42$, and 128 (October 20) days after application to the wetland. Water samples were collected at two depths in the water column, one at midcolumn, which was fixed at $0.5 \mathrm{~m}(1.6 \mathrm{ft})$ depth, and the second $0.1 \mathrm{~m}(0.3 \mathrm{ft})$ above the bottom of the wetland. The samples were collected from a boat tied at the sampling location, and a horizontal 2 L (0.5 gal) Van Dorn sampler (Van Dorn 1957) was used to isolate the water at the specified depths. The Van Dorn sampler was lowered to the appropriate depth in the open position where the remote closure was used to seal the bottle before it was pulled to the surface. To minimize contamination, two boats and two water samplers were used, one set dedicated to the untreated side of the wetland and the other to the treated side. Both the $\mathrm{C}$ and $\mathrm{T} 1$ locations were sampled on every sampling date, but T2 was not sampled on days 2,14 , or 28 . All of the $0.5 \mathrm{~m}$ and deep water samples were analyzed for thifensulfuron-methyl, DOC, and chloride ion $(\mathrm{Cl})$. Samples collected during the baseline sampling were analyzed for nutrients (total phosphorus $[\mathrm{P}]$, total dissolved $\mathrm{P}$, nitrate ion $\left[\mathrm{NO}_{3}\right]$, and ammonia $\left.\left[\mathrm{NH}_{3}\right]\right)$.

Two dedicated sediment samplers (treated and untreated) were used to collect samples of sediment at the central locations and closer to the wetland edges. The samples were taken in predetermined directions from the location marker to ensure that the samples were never collected from exactly the same location. To avoid contamination of water samples due to the disturbance, the sediment samples were taken after the water samples had been collected and other physical measurements had been taken. The 0.05 $\mathrm{m}(0.16 \mathrm{ft})$ diameter sediment sampler was pushed into the bottom sediments to obtain a core of at least $0.1 \mathrm{~m}(0.3 \mathrm{ft})$ length. The cores were stored at $4^{\circ} \mathrm{C}\left(39^{\circ} \mathrm{F}\right)$ until they were extruded (maximum of 2 days). The extruded samples were divided into surface ( 0 to $0.05 \mathrm{~m}$ depth) and deep ( 0.05 to $0.1 \mathrm{~m}$ $[0.3 \mathrm{ft}]$ depth), placed into Whirlpak polyethylene bags, and maintained at $-40^{\circ} \mathrm{C}\left(-40^{\circ} \mathrm{F}\right)$ until analysis for thifensulfuron-methyl.

Physical Measurements. The water level in the wetland was continuously recorded using a sonic sensor (SR50, Campbell Scientific,
Logan, Utah) that measures the distance between the sensor and an obstruction (in this case the water surface). Water temperature profiles were also measured continuously in both the treated and control portions of the wetland. The thermistor strings were located centrally in the wetland, $1 \mathrm{~m}(3.3 \mathrm{ft})$ to the north and south of the curtain. Depth profiles began at the bottom of the wetland, and thermistors were spaced every $0.3 \mathrm{~m}(1.0 \mathrm{ft})$. The deepest thermistor was at $1.3 \mathrm{~m}(4.3 \mathrm{ft})$ below the water surface on the treated side of the wetland and $1 \mathrm{~m}$ on the untreated side. A floating thermistor was located near the surface on the untreated side, and air temperature was recorded at the edge of the wetland where the data were recorded using a CR10 data logger (Campbell Scientific, Logan, Utah).

In addition to the continuous temperature record, water temperatures were also recorded for each sampling location at each water sampling time using a portable probe (YSI Inc. Yellow Springs, Ohio). The probe was also used to measure $\mathrm{pH}, \mathrm{EC}$, and DO corresponding to the samples that were collected.

Analytical Methods. The analytical methodology used to determine thifensulfuron-methyl concentrations in the water samples was as described by Cessna et al (2006). Briefly, each unfiltered water sample $\left(500 \mathrm{~mL}\left[30 \mathrm{in}^{3}\right]\right)$ was passed through a solid phase extraction (SPE) cartridge (Oasis Hydrophobic Lipophilic Balance [HLB] cartridge, Waters Corporation, Milford, Massachusetts), and the cartridge eluted with 95:5 acetone/methanol. The eluate was taken to dryness, and the extract residue dissolved in aqueous acetonitrile prior to analysis by LC-MS-MS (Waters 2695 high-performance liquid chromatography [HPLC] system interfaced with the Micromass Quattro Ultima triple quadrupole mass spectrometer). For samples containing $>500 \mathrm{ng}$ $\mathrm{L}^{-1}(500 \mathrm{ppt})$, the water sample was injected $(20 \mu \mathrm{L}[0.000676$ fluid oz]) directly into the LC-MS-MS system. A laboratory blank was analyzed after the calibration curve standards to ensure that there was no carryover of thifensulfuron-methyl in subsequent sample analysis. Samples were analyzed in groups of 10 that consisted of 8 sample extracts, 1 control sample, and 1 fortified sample extract. The recovery of thifensulfuron-methyl from control water fortified at $20 \mathrm{ng} \mathrm{L}^{-1}(20 \mathrm{ppt})$ was $84 \% \pm 4 \%(n=4)$, and the limit of quantification for the method was $5 \mathrm{ng} \mathrm{L^{-1 }}(5 \mathrm{ppt})$.
The analytical methodology used to determine thifensulfuron-methyl concentrations in the sediment samples was similar to that described by Degenhardt et al. (2010). The sediment samples were extracted using a pressurized liquid extraction (PLE) system (ASE 200, Dionex, Sunnyvale, California). Freeze-dried sediment (5 g [0.2 oz]) mixed with Ottawa sand $\left(10 \mathrm{~mL}\right.$ [0.6 in $\left.{ }^{3}\right]$; Fisher Scientific, Pittsburg, Pennsylvania) was added to a $33 \mathrm{~mL}\left(2 \mathrm{in}^{3}\right)$ stainless steel PLE cell equipped at the exit end of the cell with two glass fiber filters, Ottawa sand $(5 \mathrm{~mL}$ $\left.\left[0.3 \mathrm{in}^{3}\right]\right)$, and another glass fiber filter. The cell was then filled with Ottawa sand and a glass fiber filter placed at the inlet end of the cell. The packed cell was then extracted by PLE at room temperature for 5 minutes with 50/50 methanol and citric acid buffer ( $\mathrm{pH}$ $=5$ ) solution (static mode) at a pressure of $105.5 \mathrm{~kg} \mathrm{~cm}^{-2}$ (1,500 psi). The cell was then flushed with $30 \%$ volume of extraction solvent and purged with nitrogen $(\mathrm{N})$ gas for 2 minutes $\left(10.5 \mathrm{~kg} \mathrm{~cm}^{-2}\right.$ [150 psi]). The PLE system was rinsed with water between sample extractions to prevent carryover and to remove residual potassium hydroxide from the citric acid buffer. The resulting extract ( $\left.30 \mathrm{~mL}\left[1.8 \mathrm{in}^{3}\right]\right)$ was diluted with deionized water $\left(250 \mathrm{~mL}\left[15 \mathrm{in}^{3}\right]\right)$ and then subjected to SPE cleanup by passing the diluted extract passed through an Oasis HLB SPE cartridge as described for the water samples. The recovery of thifensulfuron-methyl from control sediment fortified at $10 \mu \mathrm{g} \mathrm{kg}^{-1}$ was $100 \% \pm 2 \%$, and the limit of quantification for the method was $0.2 \mu \mathrm{g} \mathrm{kg}^{-1}$.

Chloride ion concentrations were determined using an ion specific electrode with a detection limit of $2 \mathrm{mg} \mathrm{L^{-1 }}$ (2 ppm), and nutrient analysis was performed at Environment Canada's National Laboratory for Environmental Testing in Saskatoon, Saskatchewan, Canada, using standard methods as described by Elliott et al. (2001).

Calculations. Prior to calculation of $\mathrm{DT}_{50}$ values, the thifensulfulon-methyl concentrations at the shallow sampling depths were corrected for runoff inputs and evaporation using the $\mathrm{Cl}$ data. Chloride ion concentrations have previously been used by Cessna et al. (2006) to correct for the effect of evaporation on herbicide concentrations. The method uses $\mathrm{Cl}$ as a conservative tracer and normalizes herbicide concentrations using the ratio of $\mathrm{Cl}$ ion concentration on the day of application to the $\mathrm{Cl}$ ion concentration 
on the day of sampling. Small amounts of both thifensulfuron-methyl and the $\mathrm{Cl}$ ion would be present in incoming runoff water, but they would be negligible relative to the concentrations in the wetland.

The time required for $50 \%$ of the herbicide to dissipate $\left(\mathrm{DT}_{50}\right)$ was calculated by plotting the natural logarithm of the normalized herbicide concentrations against time and fitting first order reaction kinetics. When biphasic dissipation was indicated, a second, residual $\mathrm{DT}_{50}$ (representing the time for dissipation of half of the herbicide remaining at the start of the second phase) was calculated.

The proportion of the herbicide application that was associated with sediments was crudely calculated by first estimating the mass of sediment interacting with the herbicide. The sampling depth of $0.05 \mathrm{~m}$ $(0.16 \mathrm{ft})$ was used in the calculation, and a bulk density of $0.5 \mathrm{Mg} \mathrm{m}^{-3}$ (607 tn $\mathrm{ac}^{-1} \mathrm{ft}$ ) was assumed. The mass of interacting sediment was calculated as depth $\times$ wetland area $\times$ bulk density. Then, the maximum concentration of thifensulfuron-methyl in the sediment was multiplied by the mass of sediment to obtain the mass of thifensulfuron-methyl associated with sediments. This mass was then divided by the mass of herbicide applied to determine the proportion of the application associated with sediments.

Statistical Methods. The differences between wetland properties (including thifensulfuron-methyl concentrations) measured at $0.5 \mathrm{~m}(1.6 \mathrm{ft})$ and at the deeper sampling depth were tested for statistical significance using paired data for each sampling location and sampling time. A standard two-tailed paired $t$-test was used for most properties, but the nonparametric Wilcoxon's signed rank test was used where appropriate (Snedecor and Cochran 1980).

\section{Results and Discussion}

Hydrology. During most summers in the prairie region, wetland water levels would decline gradually due to evaporative demand in the subhumid climate at the study site. However, in 2005, some major rainfall events caused recharge in the wetland during the study. Figure 1 shows the water depth on the control and treated sides of the curtain during the study. Between 6:00 and 10:00 am on June 17 (the third day after herbicide addition to the wetland), $22 \mathrm{~mm}$ (0.9 in) of precipitation increased the water volume in the treated portion of the wetland by almost

\section{Figure 1}

Water depth of the control and treated sides of the wetland with time.

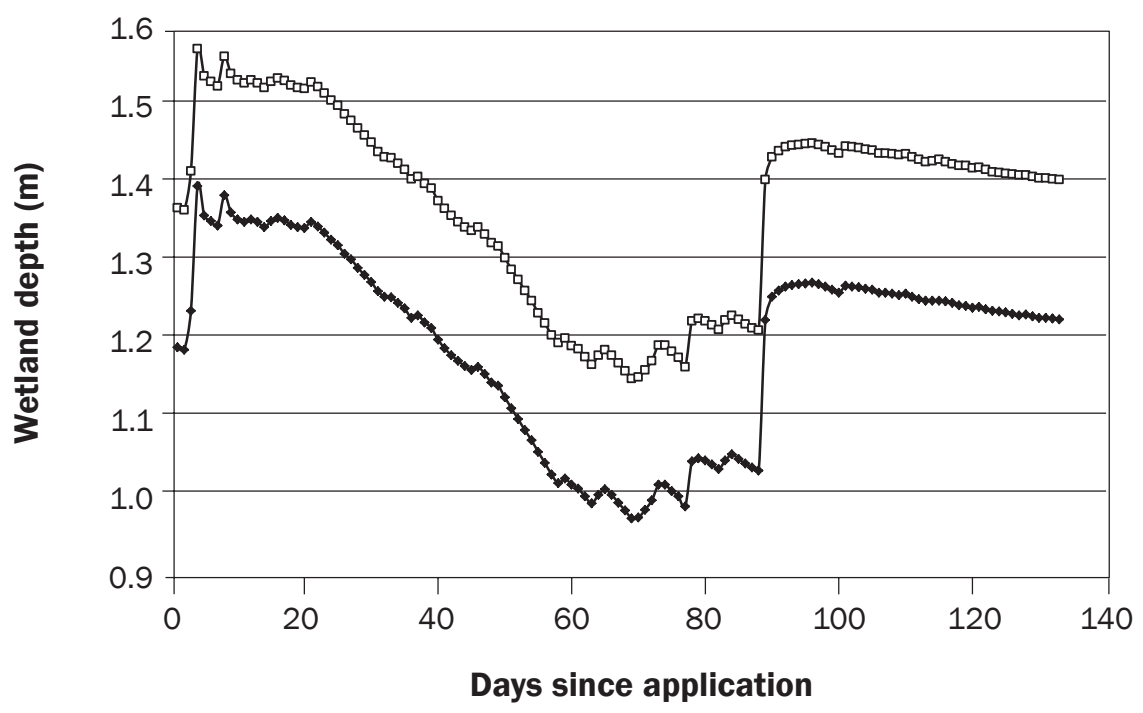

\section{Legend}

$\rightarrow$ Control $\rightarrow \square$ Treated

$20 \mathrm{~m}^{3}$ (706 $\mathrm{ft}^{3} ; \sim 10 \%$ by volume) due to both the precipitation and concurrent surface runoff. As a result, the concentration of thifensulfuron-methyl in the wetland water was diluted, but the curtain was not overtopped. However, the separating curtain was overtopped later that day when water level rose above $1.35 \mathrm{~m}(4.43 \mathrm{ft})$ on the control side of the curtain $(1.53 \mathrm{~m}$ [5.02 ft] on the treated side) due to a second rainfall $(\sim 60$ $\mathrm{mm}[2.4 \mathrm{in}])$ that occurred after the day 3 samples had been taken. Most of the surface runoff water generated in this event entered on the control side of the wetland with some passing into the treated side when the partitioning curtain was overtopped. At this time, the overall capacity of the wetland was exceeded, and some water spilled from the treated side into an adjacent wetland to the south. The two events on June 17 resulted in a total increase in water volume on the treated side of the wetland of $93 \mathrm{~m}^{3}(3,284$ $\mathrm{ft}^{3}$; almost $50 \%$ of the preevent volume).

A second overtopping occurred after sampling on day 7 when a further $22 \mathrm{~mm}(0.9$ in) of precipitation resulted in $18 \mathrm{~m}^{3}\left(635 \mathrm{ft}^{3}\right)$ of runoff entering the treated portion. After this event, the water volume in the treated portion of the wetland decreased steadily to a minimum of $110 \mathrm{~m}^{3}\left(3,885 \mathrm{ft}^{3} ; 40 \%\right.$ of maximum) in late August when the water volumes on both sides of the curtain began to rise due to precipitation input. A final major storm event on September $10(54 \mathrm{~mm}$ [2.1 in] of precipitation in a 24-hour period) caused water levels on both sides of the curtain to rise significantly, but the curtain was not overtopped.

Wetland Characteristics. The nutrient status of the wetland was only sampled during the baseline sampling. Total $\mathrm{P}$ concentrations were relatively uniform throughout the wetland and averaged $2.41 \pm 0.16 \mathrm{mg}$ $\mathrm{L}^{-1}(2.41 \pm 0.16 \mathrm{ppm})$, with $98 \%$ of $\mathrm{P}$ in the dissolved form. Concentrations of $\mathrm{NH}_{3}$ were not uniform throughout the wetland and tended to be greater and more variable at the deeper sampling locations $(0.21 \pm 0.15 \mathrm{mg}$ $\left.\mathrm{L}^{-1}[0.21 \pm 0.15 \mathrm{ppm}]\right)$ than at $0.5 \mathrm{~m}(1.6$ $\mathrm{ft})$ depth $\left(0.08 \pm 0.01 \mathrm{mg} \mathrm{L}^{-1}[0.08 \pm 0.01\right.$ ppm]). None of the samples contained $\mathrm{NO}_{3}$ at a concentration greater than the detection limit (0.01 $\left.\mathrm{mg} \mathrm{L}^{-1}[0.01 \mathrm{ppm}]\right)$. These concentrations indicated that the wetland was hypereutrophic and that production in the wetland was primarily $\mathrm{N}$-limited (Environment Canada 2004).

Water temperature measured in conjunction with sampling was significantly greater at $0.5 \mathrm{~m}(1.6 \mathrm{ft})$ depth in the water column than at $0.1 \mathrm{~m}(0.3 \mathrm{ft})$ above the bottom of the wetland (table 1) until the last sampling date when water temperatures at $0.5 \mathrm{~m}$ became cooler due to lower ambient temperatures. Using the continuous temperature record collected from the thermistor strings (figure 
2), September 12 (day 90 since application) was identified as the day when the deeper sampling location started to be warmer than at $0.5 \mathrm{~m}$ depth. Throughout the study, the water temperature at the $0.5 \mathrm{~m}$ depth was influenced by the ambient air temperature to a much greater degree (temperatures ranged between $5^{\circ} \mathrm{C}$ and $20^{\circ} \mathrm{C}\left[41^{\circ} \mathrm{F}\right.$ and $\left.\left.68^{\circ} \mathrm{F}\right]\right)$ than at the deeper sampling depth $\left(9^{\circ} \mathrm{C}\right.$ and $14^{\circ} \mathrm{C}\left[48^{\circ} \mathrm{F}\right.$ and $\left.\left.57^{\circ} \mathrm{F}\right]\right)$. The strong diurnal temperature fluctuation at the $0.5 \mathrm{~m}$ sampling depth (average amplitude $0.8^{\circ} \mathrm{C}\left[0.4^{\circ} \mathrm{F}\right]$ ) was significantly greater than that measured at the deeper sampling depth $\left(0.2^{\circ} \mathrm{C}\left[0.1^{\circ} \mathrm{F}\right]\right)$. Close to the water surface at $0.1 \mathrm{~m}(0.3 \mathrm{ft})$ depth, the amplitude of the diurnal temperature fluctuation frequently exceeded $20^{\circ} \mathrm{C}$ $\left(36^{\circ} \mathrm{F}\right)$, whereas the maximum fluctuation observed at the $0.5 \mathrm{~m}$ depth was $3.5^{\circ} \mathrm{C}\left(6^{\circ} \mathrm{F}\right)$ and that at depth did not exceed $1^{\circ} \mathrm{C}\left(2^{\circ} \mathrm{F}\right)$. The temperature gradients established in the wetland reflect incomplete mixing of the wetland water. While incomplete mixing is normal for prairie wetlands, the situation in this wetland may be extreme as the installation of the curtain has created two wetlands with disproportionally high depth to surface area ratios, which would be less effectively mixed by wind action.

As with water temperature, EC also differed significantly with depth, further evidence that the wetland was not well mixed. However, in contrast to water temperature, EC was less at $0.5 \mathrm{~m}(1.6 \mathrm{ft})$ depth than deeper in the wetland. The average EC was almost twice as great at the deeper sampling depth than at $0.5 \mathrm{~m}$ depth (table 1 ) but values at both depths would be classified as moderately saline (Millar 1976). Although the deeper sampling depth was consistently more saline than at $0.5 \mathrm{~m}$, there was considerable variation in EC with time (figure 3). When thifensulfuron-methyl was added to the wetland, EC at the $0.5 \mathrm{~m}$ sampling depth $\left(2,218 \pm 17 \mu \mathrm{S} \mathrm{cm} \mathrm{cm}^{-2}\right)$ was similar to that at greater depth of $0.1 \mathrm{~m}$ above the bottom $\left(2,683 \pm 441 \mu \mathrm{S} \mathrm{cm} \mathrm{cm}^{-2}\right)$. The greater spatial variability at the deeper sampling depth was due to higher EC at sampling site T1, which was about $0.2 \mathrm{~m}$ deeper than the other two locations (T2 and C). Electrical conductivity declined slightly at the $0.5 \mathrm{~m}$ depth between days 2 and 3 in response to the rainfall event on the night of day 2 , and between days 3 and 7 it dropped sharply to $1,500 \pm 300$ $\mu \mathrm{S} \mathrm{cm}^{-2}$ as the influx of fresh runoff water mixed to $0.5 \mathrm{~m}$ depth. No dilution and cor-

\section{Table 1}

Physical characteristics of the wetland water at $0.5 \mathrm{~m}$ depth and $0.1 \mathrm{~m}$ above the bottom. Values are means (and standard deviations) of measurements made at each sampling time at the three sampling locations.

\begin{tabular}{lcccc}
\hline & \multicolumn{3}{l}{ Depth } \\
\cline { 2 - 5 } Wetland property & $\mathbf{0 . 5}$ m depth & & \multicolumn{2}{l}{$\mathbf{0 . 1}$ above bottom } \\
\hline Temperature $\left({ }^{\circ} \mathrm{C}\right)$ & 15.4 & $(3.5) \mathrm{a}$ & 12.2 & $(1.8) \mathrm{b}$ \\
$\mathrm{EC}\left(\mu \mathrm{Sm}^{-2}\right)$ & 2.6 & $(0.7) \mathrm{b}$ & 4.5 & $(1.4) \mathrm{a}$ \\
$\mathrm{DO}\left(\mathrm{mg} \mathrm{L}^{-1}\right)$ & 2.0 & $(2.8) \mathrm{a}$ & 0.4 & $(0.3) \mathrm{b}$ \\
$\mathrm{pH}$ & 7.4 & $(0.2) \mathrm{a}$ & 6.9 & $(0.2) \mathrm{b}$ \\
$\mathrm{DOC}\left(\mathrm{mg} \mathrm{L}^{-1}\right)$ & 39.2 & $(4.0) \mathrm{a}$ & 39.1 & $(2.4) \mathrm{a}$ \\
\hline
\end{tabular}

Notes: $\mathrm{EC}=$ electrical conductance. $\mathrm{DO}=$ dissolved oxygen. $\mathrm{DOC}=$ dissolved organic carbon. Values on the same line followed by the same letter are not significantly different at $p \leq 0.05$.

\section{Figure 2}

Daily mean temperatures in the treated portion of the wetland at $0.1 \mathrm{~m}$ (deep) and $0.7 \mathrm{~m}$ (shallow) above the wetland bottom. The dashed lines on either side of the means indicate the daily maximums and minimums at each depth. The fixed depth of $0.7 \mathrm{~m}$ above the wetland bottom varied between approximately $0.5 \mathrm{~m}$ and $0.85 \mathrm{~m}$ below the water surface during the measurement period.

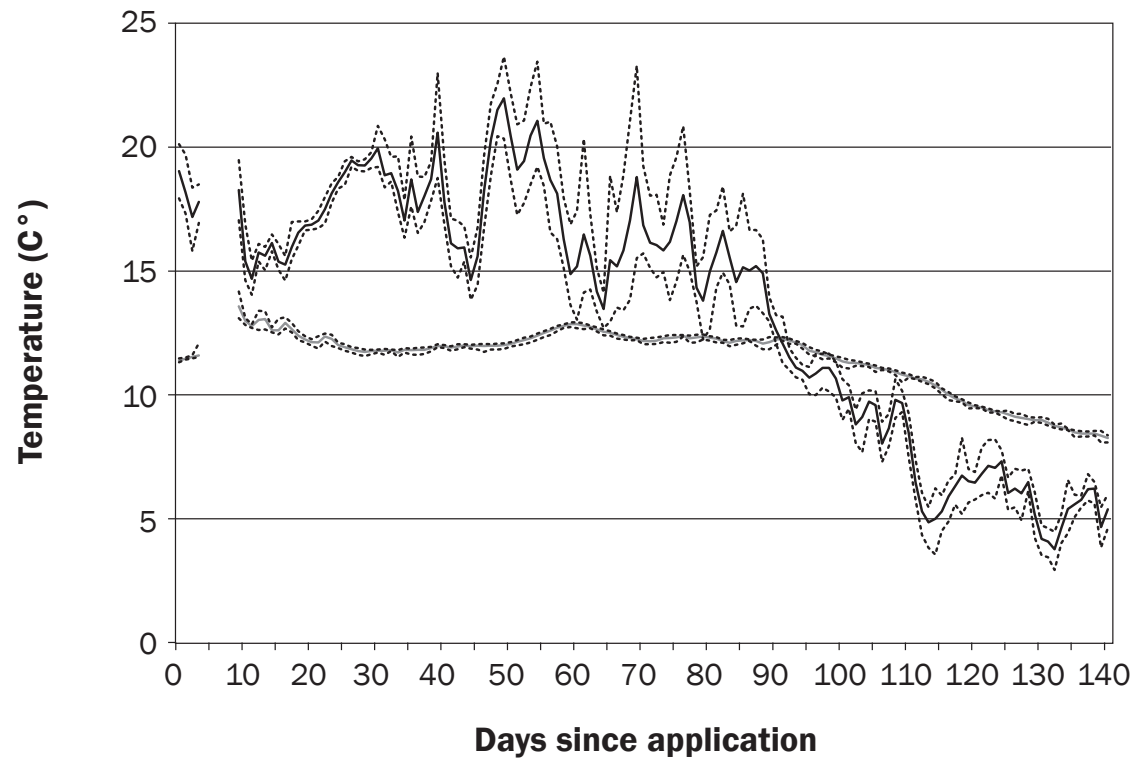

\section{Legend}

— Deep mean Shallow mean

responding drop in EC was observed at the deeper sampling depths where EC began to increase after day 3 and continued to increase until day 42 when it stabilized at around $6,000 \mu \mathrm{S} \mathrm{cm} \mathrm{cm}^{-2}$. Most of this increase in EC was likely due to an influx of saline water from beneath the wetland. Infiltrating water from the heavy precipitation would have raised the water table resulting in discharge of saline groundwater into the wetland. The influx of higher EC water was also evident at the $0.5 \mathrm{~m}$ sampling depth after day 7 , but the increase in EC was not as great as at the deeper sampling locations.

Dissolved $\mathrm{O}$ concentrations at the deeper sampling locations remained low $\left(<1 \mathrm{mg} \mathrm{L}^{-1}\right.$ $[<1 \mathrm{ppm}])$ and relatively constant throughout the sampling period. Although the concentration of DO was significantly greater at the $0.5 \mathrm{~m}(1.6 \mathrm{ft})$ sampling locations (table 1), it was more variable and, during the summer, overlapped with concentrations at depth on some days and exceeded them with concentrations between 1 and $3 \mathrm{mg} \mathrm{L}^{-1}$ (1 and 3 


\section{Figure 3}

Electrical conductivity of the wetland water with time at $0.5 \mathrm{~m}$ depth and at $0.1 \mathrm{~m}$ above the wetland bottom for sites, C, T1, and T2.

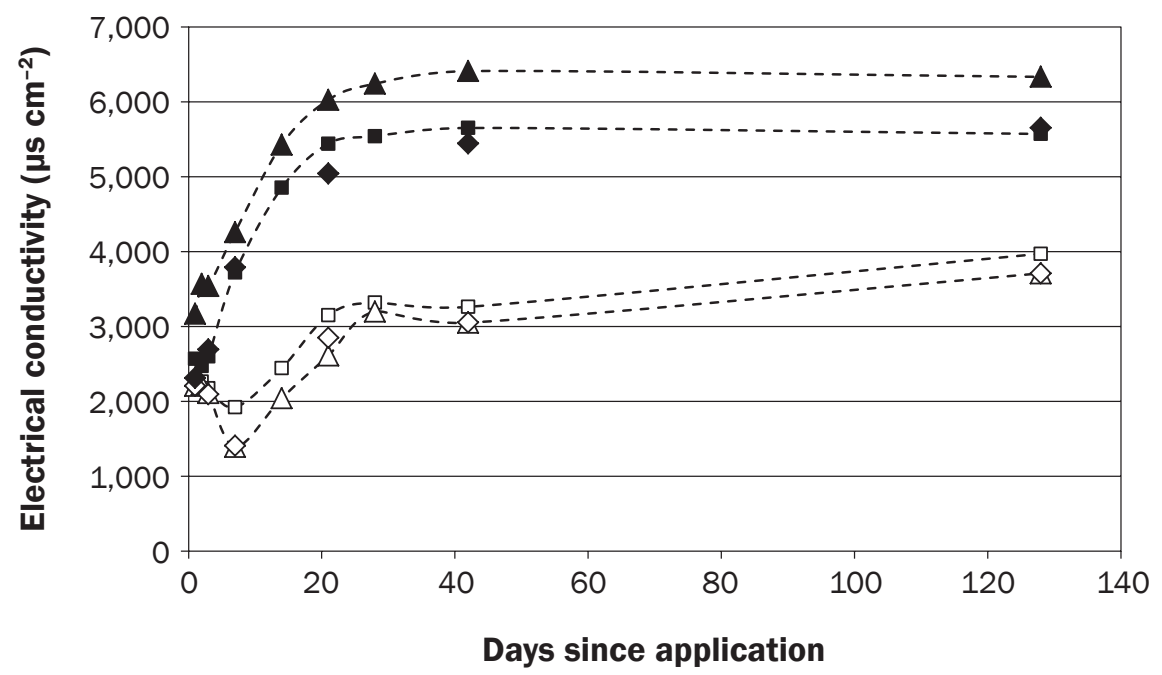

Legend

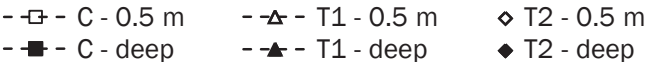

ppm) on other days. On the final sampling day (day 128 or October 20) DO at 0.5 $\mathrm{m}$ depth was $9.6 \pm 0.5 \mathrm{mg} \mathrm{L}^{-1}(9.6 \pm 0.5$ $\mathrm{ppm})$ presumably due to reduced microbial activity in the cooler fall temperatures, but there was no corresponding increase at the deeper sampling locations, again indicative of a poorly mixed wetland.

There was little variability in $\mathrm{pH}$ with sampling time, and although the $\mathrm{pH}$ at depth $(6.9 \pm 0.2)$ was significantly lower than at the shallow sampling locations $(7.4 \pm 0.2)$, the water at both locations had neutral $\mathrm{pH}$. Dissolved organic C did not vary in magnitude with depth in the wetland but was more variable at $0.5 \mathrm{~m}(1.6 \mathrm{ft})$ than at depth. Dissolved organic C at both sampling depths remained relatively constant throughout the sampling period. The concentration of DOC was relatively high ranging from 30 to $45 \mathrm{mg}$ $\mathrm{L}^{-1}$ (30 to $45 \mathrm{ppm}$ ), which is typical for saline ponds (Waiser 2006). In summary, the wetland environment at the shallow sampling location $(0.5 \mathrm{~m})$ was warmer, less saline, better aerated, and slightly more alkaline than at the deeper locations. These trends and the magnitudes of the reported physico-chemical properties are within the normal range of those observed at the St. Denis National Wildlife Area (Environment Canada 1998). The values for DO are toward the lower end of the reported ranges, but this likely reflects the somewhat deeper sampling in our study. and T2 over time. At the deeper sampling depths, the concentration in the sample taken on day 1 at T1 (the deepest site) was only $0.59 \mu \mathrm{g} \mathrm{L^{-1 }}(0.59 \mathrm{ppb})$ compared to $3.14 \mu \mathrm{g} \mathrm{L}^{-1}(3.14 \mathrm{ppb})$ at T2, and the lower concentration at T1 was supported by the similarly lower concentration measured at the same sampling location the following day (figure 4). Throughout the rest of the sampling period, concentrations at depth at T1 were similar to or less than those measured at depth at T2, but remained markedly lower than those measured at $0.5 \mathrm{~m}$ (figure 3 ).

None of the concentrations measured in the wetland reached the target concentration of $12 \mu \mathrm{g} \mathrm{L}^{-1}$ (12 ppb), but on day 1 concentrations at the shallow sampling depth were $9.49 \pm 0.10 \mu \mathrm{g} \mathrm{L}^{-1}(9.49 \pm 0.10 \mathrm{ppb}$ ) (figure 4). It is reasonable that the concentration on day 1 be less than the target concentration because some dissipation would have taken place during the 24 hours since application, but the much lower concentrations measured at depth cannot be explained by dissipation. The target concentration assumed that the herbicide would be evenly distributed through the wetland. The increase in concentration noted at depth at T1 from days 1 to 3 indicates that it took some time for the surface application $(<0.1 \mathrm{~m}$ depth) to spread through the wetland. Although the herbicide was found throughout the treated part of the wetland on day 1 , the lower concentrations measured at the deeper sampling depths throughout the study indicate that wetland was never fully mixed, and an even distribution of herbicide was not obtained. Given the apparent stratification, concentrations nearer the surface of the wetland on day 1 would likely have been in excess of the target concentration.

The influxes of water to the wetland that occurred on days 3 and 7 due to rainfall likely diluted the thifensulfuron-methyl in the wetland water on the treated side, but unlike EC (figure 3), which showed a clear dilution effect, the effect on thifensulfuron-methyl is confounded by the dispersion of the herbicide deeper in the wetland (figure 3). In addition, the incoming runoff water would contain some of the thifensulfuron-methyl that was applied to the wetland catchment on day -4 . Elliott and Cessna (2010) measured thifensulfuron-methyl in runoff water from fields that had been treated at a rate similar to the field application in this study 5 and 6 days prior to 


\section{Figure 4}

Concentrations of thifensulfon-methyl and chloride in the wetland after application of the herbicide. Thifensulfuron-methyl concentrations are shown for sampling sites ( $T_{1}$ and $T_{2}$ ) in the treated portion of the wetland, and chloride concentrations are the means and standard deviations (error bars) of measurements at $0.5 \mathrm{~m}$ depth in the control and treated portions of the wetland.

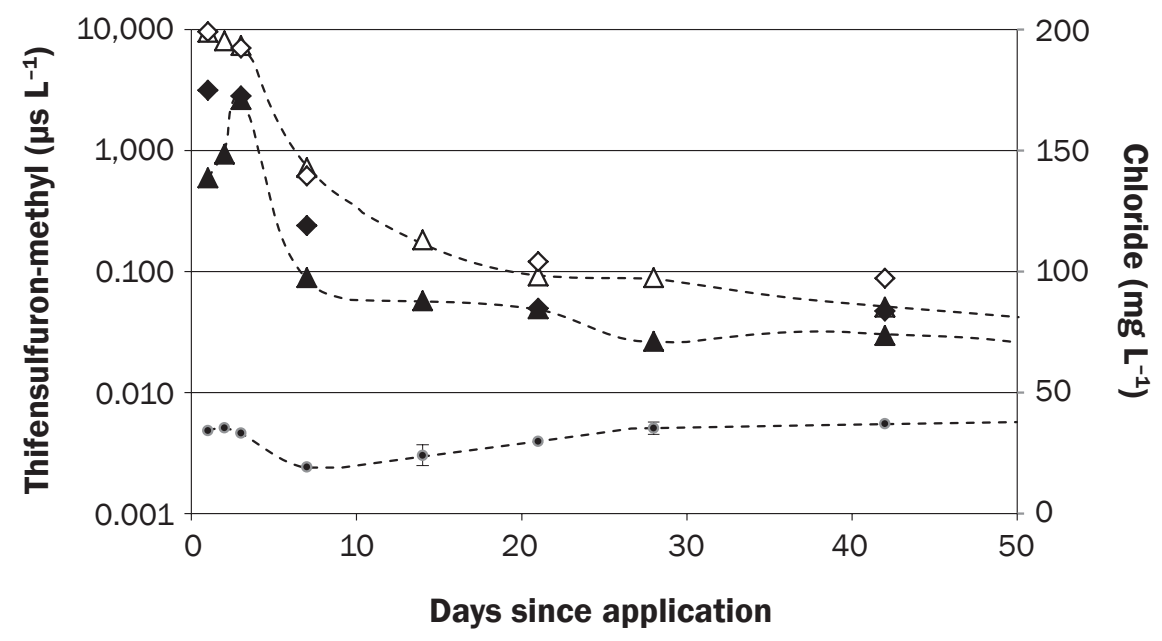

Legend

$--\Delta-\mathrm{T} 1-0.5 \mathrm{~m}$

$-\$-\mathrm{T} 1$ - deep

- T2 - $0.5 \mathrm{~m}$

- - - - Chloride

$\diamond \mathrm{T} 2$ - deep

runoff and found flow-weighted mean concentrations of thifensulfuron-methyl in the runoff water averaging $0.2 \mu \mathrm{g} \mathrm{L}^{-1}(0.2 \mathrm{ppb})$. If we use this concentration as an estimate of the thifensulfuron-methyl in the runoff water in the current study on days 2 and 3 (6 and 7 days after the field application), the incident water would have had little impact on thifensulfuron-methyl concentrations on the control side of the wetland because the wetland water and the incoming runoff would have had similar concentrations. On the treated side of the wetland, the incoming water would have diluted the wetland water because the thifensulfuron-methyl concentration in the runoff was estimated to be approximately $4 \%$ of the average concentration in the wetland on day 3. Therefore changes in thifensulfuron-methyl concentration in the treated portion of the wetland between days 2 and 3, days 3 and 7, and days 7 and 14 reflect both dissipation of thifensulfuron-methyl and dilution by runoff water.

Dissipation of Thifensulfuron-Methyl in Wetland Water. The influx of fresh water into the wetland on days 2,3, and 7 presents difficulties for the calculation of dissipation rates for thifensulfuron-methyl. By using the amount of water that entered the wetland (93 $\left.\mathrm{m}^{3}\left[3,284 \mathrm{ft}^{3}\right]\right)$ and estimating the thifensul- fon-methyl concentration in the incoming runoff water $\left(0.2 \mu \mathrm{g} \mathrm{L}^{-1}\right.$ [0.2 ppb]; Elliott and Cessna 2010), we calculated that a relatively insignificant amount $(19 \mathrm{mg}[0.0007 \mathrm{oz}]$ or less than $1 \%$ of the amount added) of thifensulfuron-methyl was added to the wetland by the runoff events. However, the mixing of the fresh water with the wetland water was incomplete (figure 3), and therefore the effect on thifensulfuron-methyl concentration at each sampling location cannot be accurately determined.

\section{Table 2}

Regression coefficients $\left(r^{2}\right)$ for dissipation plots (natural logarithm of normalized concentration against time) of thifensulfuron-methyl with time and calculated initial (days 1 to 14) and residual (days 21 to 128 ) time for $50 \%$ dissipation ( $\mathrm{DT}_{50}$ ) values for sampling locations $\mathrm{T}_{1}$ and $\mathrm{T}_{2}$ at $0.5 \mathrm{~m}$ below surface and at $0.1 \mathrm{~m}$ above the wetland bottom.

\begin{tabular}{|c|c|c|c|c|c|c|}
\hline \multirow[b]{2}{*}{ Location } & \multicolumn{2}{|c|}{ All data } & \multicolumn{2}{|c|}{ Initial } & \multicolumn{2}{|c|}{ Residual } \\
\hline & $r^{2}$ & $\mathrm{DT}_{50}(\mathrm{~d})$ & $r^{2}$ & $\mathrm{DT}_{50}(\mathrm{~d})$ & $r^{2}$ & $\mathrm{DT}_{50}$ (d) \\
\hline \multicolumn{7}{|l|}{$0.5 \mathrm{~m}$} \\
\hline $\mathrm{T} 1$ & 0.66 & - & 0.98 & 2.3 & 0.99 & 27.0 \\
\hline $\mathrm{T} 2$ & 0.79 & - & 0.95 & 1.7 & 1.00 & 22.5 \\
\hline \multicolumn{7}{|l|}{ Deep } \\
\hline $\mathrm{T} 1$ & 0.60 & - & 0.66 & 2.9 & 0.94 & 34.1 \\
\hline $\mathrm{T} 2$ & 0.74 & - & 0.92 & 1.8 & 0.98 & 27.0 \\
\hline
\end{tabular}

The thifensulfuron-methyl concentrations at the shallow sampling depth were normalized using the $\mathrm{Cl}$ data (figure 4) prior to calculation of DT50 values. The ratios of initial $\mathrm{Cl}$ concentration to that at time of sampling $\left(\left[\mathrm{Cl}_{\mathrm{o}} / \mathrm{Cl}_{\mathrm{t}}\right]\right.$ used to normalize the data ranged from a high of 1.75 on day 7 to a low of 0.77 on day 128 .

Plotting the natural logarithm of the normalized herbicide concentrations against time did not result in the linear relationship exhibited by a first order reaction (table 2). However, the initial dissipation of up to $10 \%$ of the herbicide remaining (days 1 to 14) was linear, and a $\mathrm{DT}_{50}$ was calculated for each sampling location. A second, residual $\mathrm{DT}_{50}$ (representing the time for dissipation of half of the herbicide remaining on day 21) was calculated for the period from day 21 to 128 and was also linear. Of the eight slope segments that were analyzed, only the initial dissipation at the deepest sampling depth was a poor fit to the linear relationship (table 2). Thifensulfuron-methyl concentrations at this depth increased until day 3 as the herbicide dispersed through the wetland, and dissipation only became apparent on day 7 . The deepest sampling depth had the longest initial (2.9 days) and residual (34.1 days) $\mathrm{DT}_{50}$ values, and the shortest $\mathrm{DT}_{50}$ values $(1.7$ and 22.5 days $)$ were measured at $0.5 \mathrm{~m}(1.6 \mathrm{ft})$ at T2 (table 2). At both T1 and T2, dissipation at $0.5 \mathrm{~m}$ was faster than at depth but there was no clear influence of sampling depth on dissipation rate because the residual $\mathrm{DT}_{50}$ for $\mathrm{T} 1$ at $0.5 \mathrm{~m}$ was the same as that for T2 at depth.

Despite significant differences in temperature, EC, pH, and DO between $0.5 \mathrm{~m}$ (1.6 $\mathrm{ft}$ ) and at depth, the differences were insufficient to impact dissipation rates. However, the initial dissipation rates measured in this 
study ( $2.2 \pm 0.6$ days $)$ were faster than the initial dissipation rates of 16 days reported by Cessna et al. (2006) who also observed biphasic dissipation of thifensulfuron-methyl. Cessna's study was conducted under similar climatic conditions as those in our study but in dugout water rather than wetland water. The dugout water had higher $\mathrm{pH}$ (8.4 versus 7.4) and lower DOC (11.5 versus 39.2 $\mathrm{mg} \mathrm{L}^{-1}$ [11.5 versus $\left.39.2 \mathrm{ppm}\right]$ ) than the wetland water. There may be some effect of $\mathrm{pH}$ on dissipation because sulfonylurea herbicides would be more stable to hydrolysis (Sarmah and Sabadie 2002) and more water soluble (WSSA 1994) in the less acidic dugout conditions. The higher DOC in the wetland would likely have reduced herbicide dissipation through photolysis due to sunlight attenuation by the DOC (Arts et al. 2000). Headley et al. (2010) determined that approximately $30 \%$ of thifensulfuron-methyl dissipation in a thin layer of pond water was due to photolysis, but it is unlikely that photolysis would have been significant in either water body at the sampling depths used. However, the high DOC environment of the wetland would be conducive to the activity of primary producers (e.g., bacteria), and more herbicide dissipation due microbial degradation would be likely. Another difference between Cessna's dugout and our wetland is the presence of aquatic plants that could act as a sink for thifensulfuron-methyl through sorption or uptake and thus increase the observed dissipation from the water column. Mohammad et al. (2005) have reported uptake of thifensulfuron-methyl by one of the aquatic plants present in the study wetland (Lemna sp).

Concentrations of Thifensulfuron-Methyl in Wetland Sediments. Thifensulfuronmethyl was only detected in 3 of the 24 sediment samples that were analyzed. None of the samples that were collected during the baseline sampling on June 9 or the samples collected on the control side of the wetland contained detectable thifensulfuron-methyl. After thifensulfuron-methyl was added to the wetland, the herbicide was not detected at any time at the primary sampling locations on the treated side of the wetland (T1 and T2). However, thifensulfuron-methyl was measured in both samples from the supplementary sampling locations near the wetland margins on the treated side of the wetland (T3 and T4) on day 3 after herbicide addition $\left(1.8\right.$ and $1.1 \mu \mathrm{g} \mathrm{kg}^{-1}$ ) and again at site $\mathrm{T} 4 \mathrm{on}$ day $7\left(0.8 \mu \mathrm{g} \mathrm{kg}^{-1}\right)$. No thifensulfuron-methyl was detected in any of the sediment samples taken on day 21 . The maximum concentration of thifensulfuron-methyl in the sediment corresponded to the day when the maximum concentration was measured in the deep water sample from T1, the deepest sampling location in the wetland (figure 3). By day 21, when thifensulfuron-methyl was not detected in the sediments, the concentration of thifensulfuron-methyl in the deep water samples was less than $0.05 \mu \mathrm{g} \mathrm{L}^{-1}(0.05 \mathrm{ppb})$. The concentrations measured in T3 and T4 on day 2 and T4 on day 7 were greater than those measured by Degenhardt et al. (2010) who surveyed 17 wetlands in Saskatchewan and Manitoba for thifensulfuron-methyl and found trace concentrations $\left(<0.2 \mu \mathrm{g} \mathrm{kg} \mathrm{kg}^{-1}\right)$ in $39 \%$ of the samples. Since Degenhardt's survey samples were not collected immediately following a catchment application, it is not surprising that the herbicide was not detected in quantifiable amounts.

Thifensulfuron-methyl was only found in the shallower sediments, so using the bathymetry of the wetland, we assumed that only $50 \%$ of the sediments were shallow and that only $50 \%$ of the sediment mass interacted with the herbicide. Therefore, thifensulfuron-methyl was present in $150 \mathrm{~m}^{2}$ $\left(1,615 \mathrm{ft}^{2} ; 50 \%\right.$ of area $\left.300 \mathrm{~m}^{2}\left[3,229 \mathrm{ft}^{2}\right]\right)$ of sediment that extended to the sampling depth of $0.05 \mathrm{~m}(0.16 \mathrm{ft})$ and weighed 3.75 $\mathrm{Mg}$ (3.69 tn). The maximum concentration of thifensulfuron-methyl in the sediment averaged $1.45 \mu \mathrm{g} \mathrm{kg}^{-1}$ (day 3), resulting in $5.44 \mathrm{mg}(0.0002 \mathrm{oz})$ or approximately $0.23 \%$ of the $2.4 \mathrm{~g}(0.08 \mathrm{oz})$ added to the wetland being associated with the wetland sediments. The assumption of interaction of only $50 \%$ of the sediment with thifensulfuron-methyl was somewhat arbitrary, but using a range of interaction from $10 \%$ to $90 \%$, the proportion of thifensulfuron-methyl associated with the sediments ranged from $0.05 \%$ to $0.41 \%$. In comparison, Goldsborough and Crumpton (1998) reported sorption to sediments as the major pathway for pesticide dissipation in wetland mesocosms, and Degenhardt (2010) and Degenhardt et al. (2011) found much larger proportions of applications associated with sediment $(10 \%$ to $67 \%$ for glyphosate; $1 \%$ to $53 \%$ of a suite of acid herbicides). Herbicide properties do not give an explanation for the small proportion of thifensulfon-methyl in sediment. Reported values for water solubility $\left(2.24 \mathrm{mg} \mathrm{L}^{-1}\right.$ [2.24 ppm] and $\mathrm{pH}=7$ ) and herbicide sorption per unit organic $\mathrm{C}\left(\mathrm{k}_{\mathrm{oc}}=13\right.$ to $55 \mathrm{~mL} \mathrm{~g}^{-1}$ [110 to

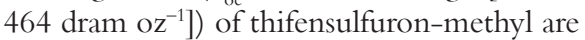
within the range of values for the herbicides in Degenhardt's studies (USDA ARS 2001). The same source also reported low values for the soil water partition coefficient $\left(\mathrm{k}_{\mathrm{d}}=\right.$ 0.08 to 1.38$)$. The rapid dissipation of thifensulfuron-methyl in the water column of the wetland relative to most of the rates measured by Degenhardt (2010) and Degenhardt et al. (2011) and the lack of mixing between surface and deep water in the water column resulted in only a small proportion of the thifensulfuron-methyl added to the wetland being found in the wetland sediments.

\section{Summary and Conclusions}

Thifensulfuron-methyl demonstrated a biphasic dissipation in the wetland water column characterized by an initial rapid dissipation $\left(\mathrm{DT}_{50}\right.$ value $=2.2 \pm 0.6$ days $)$ that after 14 days was followed by slower rate of dissipation $\left(\mathrm{DT}_{50}\right.$ value $=27.6 \pm 4.8$ days $)$. Quantifiable concentrations of thifensulfuron-methyl were measured in wetland sediments near the wetland margins 3 and 7 days after application, but no thifensulfuron-methyl was detected in the deeper sediments. Partitioning into wetland sediments was not a major dissipation pathway for thifensulfuron-methyl since the maximum amount of the herbicide estimated to be associated with the sediments (day 3) corresponded to approximately $0.23 \%$ of the application. The lack of persistence of thifensulfuron-methyl in either the wetland water or sediments suggests that it poses a relatively low risk to prairie wetland environments, but this should be confirmed by a study of its ecological effects.

The wetland water was not well mixed. Temperatures were higher and more variable at $0.5 \mathrm{~m}(1.6 \mathrm{ft})$ depth than at the deeper sampling locations until mid-September. Dissolved $\mathrm{O}$ and $\mathrm{pH}$ were significantly greater at $0.5 \mathrm{~m}$ depth than deeper in the wetland, and the reverse was true for EC, which was greatest at depth. The incomplete mixing resulted in less thifensulfuron-methyl reaching the deeper sampling locations and contacting wetland sediments than was present in the surface water. Concentrations throughout the study were consistently lower at the deeper sites than at $0.5 \mathrm{~m}$ depth.

Although there was incomplete mixing of the herbicide in the wetland and significant 
differences in physical characteristics at the different sampling locations, the impact on dissipation of thifensulfuron-methyl was small. A single sampling location within a wetland does not capture the variability in conditions. However, if the location is not biased through proximity to the wetland surface, sediments or edge, a standardized sampling location (e.g., 0.5 $\mathrm{m}$ [1.6 ft] depth at wetland center) could be used as a cost-effective way to compare different wetland environments.

\section{Acknowledgements}

We would like to acknowledge the technical support provided by David Gallen and Jon Bailey; both research technicians in Saskatoon, Saskatchewan. David Donald, a biologist in Regina, Saskatchewan, Nancy Glozier, a biologist in Regina, Saskatchewan, Marley Waiser, a research scientist, Saskatoon, Saskatchewan, and Dani Degenhardt, a postdoctoral fellow, Saskatoon, Saskatchewan, all made scientific contributions to the project. The study was carried out at the St. Denis National Wildlife Area and was funded by Environment Canada's Pesticide Science Fund.

\section{References}

Acton, D.F., and J.G. Ellis. 1978. The soils of the Saskatoon map area 73-B Saskatchewan. Saskatchewan Institute of Pedology Publication S4. Saskatoon, SK, Canada: Saskatchewan Institute of Pedology.

Arts, M.T., R.D. Robarts, F. Kasai, M.J. Waiser, V.P. Tumber, A.J. Plante, H. Rai, and H.J. Lange. 2000. The attenuation of ultraviolet radiation in high dissolved organic carbon waters of wetlands and lake on the northern Great Plains. Limnology and Oceanography 45:292-299.

Batt, B.D.J., M.G. Anderson, C.D. Anderson, and F.D. Caswell. 1989. The use of prairie potholes by North American ducks. In Northern Prairie Wetlands, ed. A. van derValk, 204-227. Ames, IA, USA: Iowa State University Press.

CCME (Canadian Council of Ministers of the Environment). 2013. Canadian Environmental Quality Guidelines On-line. http://st-ts.ccme.ca/.

Cessna, A.J., D.B. Donald, J. Bailey, M. Waiser, and J.V. Headley. 2006. Persistence of the sulfonylurea herbicides thifensulfuron-methyl, ethametsulfuron-methyl and metsulfuron-methyl in farm dugouts (ponds). Journal of Environmental Quality 35:2395-2401.

Cessna, A.J., and J.A. Elliott. 2004. Seasonal variation of herbicide concentration in prairie farm dugouts. Journal of Environmental Quality 33:302-315.

Day, K.E., N.K. Kaushik, and K.R. Solomon. 1987. Impact of fenvalerate on enclosed freshwater planktonic communities and on in situ rates of filtration of zooplankton. Canadian Journal of Fish and Aquatic Science 44:1714-1728.

Degenhardt, D. 2010. Herbicide dynamics in prairie wetlands. Ph.D. dissertation. University of Saskatchewan, Saskatoon, SK, Canada.
Degenhardt, D., A.J. Cessna, R. Raina, D.J. Pennock, and A Farenhorst. 2010. Trace level determination of selected sulfonylurea herbicides in wetland sediments by liquid chromatography electrospray tandem mass spectrometry. Journal of Environmental Science and Health. B 45:11-24.

Degenhardt, D., R. Raina, A.J. Cessna, A. Farenhorst, and D.J. Pennock. 2011. Dissipation of six acid herbicides in water and sediment of two Canadian prairie wetlands. Environmental Toxicology and Chemistry 30:1982-1989.

Detenbeck, N.E., C.M. Elonen, D.L. Taylor, A.M. Cotter, F.A. Puglisi, and W.D. Saville. 2002. Effects of agricultural activities and best management practices on water quality of seasonal prairie pothole wetlands. Wetlands Ecology and Management 10:335-354

Donald, D.B., N.P. Gurprasad, L. Quinnett-Abbott, and K. Cash. 2001. Diffuse geographic distribution of herbicides in northern prairie wetlands. Environmental Toxicology and Chemistry 20:273-279.

Donald, D.B., and J. Syrgiannis 1995. Occurrence of pesticides in prairie lakes in Saskatchewan in relation to drought and salinity. Journal of Environmental Quality 24:266-270.

Donald, D.B., J. Syrgiannis, F. Hunter, and G.Weiss. 1999 Agricultural pesticides threaten the ecological integrity of northern prairie wetlands. Science of the Total Environment 231:173-181

Elliott, J.A., A.J. Cessna, and C.R. Hilliard. 2001. The influence of tillage system on water quality and quantity in prairie pothole wetlands. Canadian Water Resources Journal 26:165-181.

Elliott, J.A., and A.J. Cessna. 2010. Transport of two sulfonylurea herbicides in runoff from border dyke irrigation. Journal of Soil and Water Conservation 65(5):298-303, doi:10.2489/ jswc.65.5.298.

Environment Canada. 1998. An overview of wetland water chemistry on the St. Denis National Wildlife Area (Saskatchewan) 1993-1996. Ottawa, ON, Canada: National Wildlife Service.

Environment Canada. 2004. Canadian Guidance Framework for the Management of Phosphorus in Freshwater Systems. Ecosystem Health: Science-based Solutions Report No. 1-8. National Guidelines and Standards Office, Water Policy and Coordination Directorate, Environment Canada, Ottawa, ON, Canada

Goldsborough, L.G., and W.G. Crumpton. 1998. Distribution and environmental fate of pesticides in prairie wetlands. Great Plains Research 8:73-95

Grover, R. 1988. Environmental Chemistry of Herbicides. Volume 1. CRC Press Inc., Boca Raton, FL, USA.

Hartland-Rowe, R. 1966. The fauna and ecology of temporary pools in Western Canada.Verhandlungen des Internationalen Verein Limnologie 16:577-584.

Headley, J.V., J.L. Du, K.M. Peru, and D.W. McMartin. 2010 Mass spectrometry of the photolysis of sulfonylurea herbicides in prairie waters. Mass Spectrometry Reviews 29:593-605.
Katagi,T. 2006. Behavior of pesticides in water-sediment systems. Reviews of Environmental Contamination and Toxicology 187:133-251.

Meyboom, P. 1966. Unsteady groundwater flow near a willow ring in hummocky moraine. Journal of Hydrology 4:38-62. Millar, J.B. 1976. Wetland classification in western Canada: A guide to marshes and shallow open water wetlands in the grasslands and parklands of the prairie provinces. Canadian Wildlife Service Report Series No. 37, Environment Canada, Ottawa, ON, Canada.

Mohammad, M., T. Kishimoto, K. Itoh, K. Suyama and H. Yamamoto. 2005. Comparative sensitivity of Pseudokirchnetiella subcapita $v$ s. Lemna sp. to eight sulfonylurea herbicides. Bulletin of Environmental Contamination and Toxicology 75:866-872.

Snedecor, G.W., and W.G. Cochran. 1980. Statistical methods. 7th edition, Iowa State University Press, Ames, IA.

Sarmah, A.K., and J. Sabadie. 2002. Hydrolysis of sulfonylurea herbicides in soils and aqueous solutions: a review. Journal of Agricultural and Food Chemistry 50:6253-6265.

USDA ARS 2001. Pesticide properties database. http://wwwars. usda.gov/SP2User Files/ad_hoc/12755100DatabaseFiles/ PesticidePropertiesDatabase/Allchemicals/listallchemicals.doc.

van der Kamp, G., and M. Hayashi. 1998. The groundwater recharge function of small wetlands in the semi-arid northern prairies. Great Plains Research. 8:39-56.

Van Dorn,W.G. 1957. Large volume water sampler. Transactions of the American Geophysical Union 37:682-684.

Waiser, M.J. 2006. Relationship between hydrological characteristics and dissolved organic carbon concentration and mass in northern prairie wetlands using a conservative tracer approach. Journal of Geophysical Research 111, G02024, doi:10.1029/2005JG000088.

WSSA. 1994. Herbicide Handbook. 7th edition. W.H. Ahrens (ed.). Weed Science Society of America, Champaign, IL. USA.

Wolf, T., A.J. Cessna, B.C. Caldwell, and J.L. Pederson. 2003. Riparian vegetation reduces spray drift deposition into water bodies. In A.Thomas (ed.) Field Boundary Habitats: Implications for Weed, Insect and Disease Management. Topics in Canadian Weed Science, Volume 1. Canadian Weed Science Society, Sainte-Anne-de-Bellevue, Quebec, Canada.

Xu,D. S. Meyer,J. Gaultier,A. Farenhorst, and D.J. Pennock. 2009 Land use and riparian effects on prairie wetland sediment properties and herbicide sorption coefficients. Journal of Environmental Quality 38: 1757-1765.

Yao, Y., T. Tuduri, T. Harner, P. Blanchard, D.T. Waite, L. Poissant, C. Murphy, W. Belzer, F. Aulagnier, Y.F. Li, and E. Sverko. 2006. Spatial and temporal distribution of pesticide air concentrations in Canadian agricultural regions. Atmospheric Environment 40:4339-4351. 